\title{
O conflito apocalíptico em Assunção de Salviano, de Antonio Callado
}

\author{
The apocalyptic conflict in \\ Assunção de Salviano, by Antonio Callado \\ El conflicto apocalíptico en \\ Assunção de Salviano, de Antonio Callado
}

Geam Karlo-Gomes *

\section{Resumo}

Qual o papel da arte na formação do imaginário? Uma certeza indubitável é o fato de que nela se podem vislumbrar imagens novas, potencialmente instauradoras da renovação dos arquétipos inconscientes. Seguindo uma descrição detalhada dos últimos capítulos de Assunção de Salviano, de Antonio Callado, o intuito principal desta investigação é mostrar como a arte literária institui e renova as imagens do sagrado, sobretudo dos arquétipos do Cristo e do Anticristo. À luz da hermenêutica do imaginário de Gilbert Durand, da correlação entre o mundo alquímico dos símbolos e as experiências e conhecimentos da psicologia do inconsciente de Carl Gustav Jung, e ainda, a partir da criatividade onírica de Gaston Bachelard, foca-se na análise da travessia da personagem Salviano após sua conversão religiosa cristã e seu "grande conflito" com o líder do Partido Comunista. Desvenda-se, então, o efeito da arte literária na fabricação de novas imagens dos arquétipos inconscientes manifestados pela ação do entrechoque entre o imaginário comunista e o imaginário da doutrina cristã do paraíso perdido.

Palavras-chave: literatura, imaginário, cristianismo, comunismo.

\begin{abstract}
What is the role of art in the formation of the imaginary? An unquestionable certainty is the fact that through art one can glimpse new images, potentially instituting the renewal of unconscious archetypes. Following a detailed description of the later chapters of Assunção de Salviano, by Antonio Callado, the main purpose of this investigation is to show how literary art institutes and renews images of the sacred, especially archetypes of Christ and Antichrist. Based on the hermeneutic of Gilbert Durand's imaginary, the correlation between the alchemical world of symbols and the experiences and knowledge of the psychology of the unconscious of Carl Gustav Jung, as well as Gaston Bachelard's dream-creativity, this study analyses the development of Salviano's character after his Christian religious conversion and his "great conflict" with the leader of the Communist Party. Thus, the effect of literary art in the fabrication of new images of unconscious archetypes, manifested in the clash between the communist imaginary and the imaginary of the
\end{abstract}

\begin{abstract}
Resumen
¿Cuál es el papel del arte en la formación de lo imaginario? Una certeza indudable es el hecho de que en él se pueden vislumbrar las nuevas imágenes, potencialmente instauradoras de la renovación de los arquetipos inconscientes. Siguiendo una descripción detallada de los últimos capítulos de Assunção de Salviano, de Antonio Callado, el propósito principal de esta investigación es mostrar cómo el arte literario instituye y renueva las imágenes de lo sagrado, sobre todo de los arquetipos de Cristo y del Anticristo. A la luz de la hermenéutica del imaginario de Gilbert Durand, de la correlación entre el mundo alquímico de los símbolos y las experiencias y conocimientos de la psicología del inconsciente de Carl Gustav Jung, y aún, a partir de la creatividad onírica de Gastón Bachelard, el texto se enfoca en el análisis de la imagen de la travesía del personaje Salviano tras su conversión religiosa cristiana y su "Gran Conflicto" con el líder del Partido Comunista. Se desvela entonces el efecto del arte literario en la fabricación de nuevas imágenes de los arquetipos inconscientes manifestados por la
\end{abstract}

\footnotetext{
* Doutor em Literatura e Interculturalidade e professor da Universidade de Pernambuco, Petrolina, PE, Brasil. (Dorcid.org/00000001-9569-1497. E-mail: geamk.upe@gmail.com.
} 
Christian doctrine of a lost paradise, is consequently revealed.

Keywords: literature, imaginary, Christianity, communism. acción del entrechoque entre el imaginario comunista y el imaginario de la doctrina cristiana del paraíso perdido.

Palabras clave: literatura, imaginario, cristianismo, comunismo.

Filhinhos, esta é a última hora: e, assim como vocês ouviram que o anticristo está vindo, já agora muitos anticristos têm surgido. Por isso sabemos que esta é a última hora.

1 João, 2: 18

\section{A potência criadora de renovação das imagens}

Em Assunção de Salviano (1954), de Antonio Callado, duas perspectivas contrastantes tomam forma: enquanto alguns pensavam que "Juazeiro era efetivamente o lugar ideal para dar início à agitação comunista" (Callado, 1954, p. 11), outros "beatos e penitentes" cuidam "de fazer o Reino de Deus [...] aí mesmo, nas barrancas do S. Francisco" (Callado, 1954, p. 82). Dessa forma, configurada num contexto densamente político e religioso, um incidental conflito apocalíptico se apresenta, sobretudo em virtude do entrechoque entre as motivações provindas do ideário do Partido Comunista e das formas de expressão da doutrina cristã. Ambas sob o prisma das mesmas nostalgias de um passado glorioso e dos sonhos de um futuro radiante: estes, submersos na herança do sagrado que faz do ser humano propício à imaginação mítica, às projeções utópicas, à fabulação; aquelas, oriundas do mesmo arquétipo saudosista do paraíso desejado a sondar o imaginário do comunismo e a própria imagística da doutrina cristã.

Para Jung, arquétipo é um conceito já utilizado na antiguidade, sinonímico de "ideia" no pensamento platônico (Jung, 2012a). No entanto, diferente de Platão, a psicologia formulada por Jung provém de uma concepção na qual o arquétipo é herdado através da influência do inconsciente coletivo. Nessa psicologia profunda, existem analogias entre as imagens oníricas que provêm do homem moderno e as oriundas da mente primitiva, o que fundamenta a existência de "imagens coletivas", repletas de "motivos mitológicos". Semelhante aos extintos, que são percebidos pelos sentidos, os arquétipos se manifestam através de fantasias e podem se revelar através de "imagens simbólicas" (Jung, s/d, p. 67-69). O fato é que essas imagens são constantemente renovadas pela virtuosidade da arte literária.

Consoante à poética de Gaston Bachelard, a potência criadora da imaginação é a novidade (Bachelard, 2013). Ao habitar imagens fundamentais, arquetípicas, repletas de estruturas míticas, a literatura reanima, revitaliza, dá novos tons e volumes. Por meio das imagens, a literatura brota o que não pode ser matéria da racionalidade. Eis uma indubitável força da arte literária: a constante renovação dos arquétipos do inconsciente. Ela nos evolve numa atmosfera de imagens: múltiplas, ramificadas, associadas, derivadas do inconsciente pelo esforço do fazer literário. Isso graças a inesgotável criatividade onírica que reside na arte literária.

É também por meio da imitação dos arquétipos que o homem se projeta para uma época em que houve a revelação prototípica: a época mítica (Eliade, 1992). Por meio dela, surge a abolição do tempo profano e da imersão no tempo imemorial: o tempo sagrado. ${ }^{1}$

Embora também haja cogitações da secularização do mundo moderno, há a presença perene do sagrado. Pensando como Mircea Eliade (1992), mesmo sabendo que na modernidade a dessacralização permeia a vida do homem não religioso, torna-se difícil para o indivíduo se conservar totalmente imune aos processos de sacralização da vida. Para esse mitólogo, a existência profana jamais se encontra totalmente dessacralizada, mesmo o homem tendo optado por uma vida profana.

\footnotetext{
${ }^{1} \mathrm{O}$ tempo sagrado designa o tempo mítico e é totalmente diferente do tempo profano que o antecede, visto que se realiza pela repetição de um arquétipo mítico (Eliade, 2008, p. 314).
} 
Para Eliade, o homem não pode ser reduzido à atividade racional. Ele continua a sonhar e apaixonar-se, e essas respostas criativas da vida não são criadas pelo consciente. São essas formas de viver que permitem ao homem permanecer no território do mundo histórico e natural, e no universo existencial privado e imaginário ao mesmo tempo. Essa junção forma o que o historiador do sagrado chama de "homem total", ou seja, o ser que nunca pode ser completamente dessacralizado (Eliade, s/d, p. 12).

Para esse mitólogo e filósofo, na revelação total da realidade há uma simultânea presença do sagrado. As relações do homem com o sagrado são multiformes, propícias aos valores do Espírito. Por um lado, revela-se com o outro, o transpessoal, e por isso, é transcendente. Por outro, o sagrado também se constitui como modelos a seguir, ou seja, é exemplar, forçando os homens a sair das situações pessoais em que se encontram, ultrapassando-as a fim de ascender ao universal (Eliade, 2000).

A princípio, convém compreender, de fato, o sentido do termo sagrado. Não se trata de ser religioso no sentido de professar uma fé ou ser adepto de alguma instituição religiosa. Rudolf Otto adverte sobre o hábito de usar o sagrado num sentido figurado, como predicado de ordem ética, sinônimo do que é perfeitamente bom e absolutamente moral, próximo do que Kant denomina de vontade santa, distanciando-se do sentido primitivo original (Kujawski, 1994).

Buscando inventar um termo específico, Otto acaba retomando uma palavra já usada por Calvino: o numinoso. Atraente e cativante, "é uma categoria numinosa de interpretação e valoração". Em outras palavras: "um estado psíquico numinoso sempre ocorre no momento em que se julga tratar-se de objeto numinoso" (Otto, 2007, p. 38). Nessa acepção, trata-se de tudo que torna um aspecto paralelo entre a razão e o irracional fascinante, próprios da "experiência psíquica" e "pensado de forma consumada" (Otto, 2007, p. 69).

Essa experiência numinosa é latente na literatura. Em Assunção de Salviano, obscuro, disfarçado ou latente, um conjunto de imagens renova os arquétipos do numinoso conflito apocalíptico: o Bem e o Mal, o Cristo e o Anticristo. A menor tentativa de compreendê-lo não pode excluir a exploração do imaginário dessa trama calladiana.

Tudo tem início quando, um dia, Salgado propôs a Salviano que se fingisse de beato a fim de conquistar a confiança da camada camponesa, roubando a influência que tinham, até então, os padres. Esse fingimento deveria durar certo tempo até revelar a mistificação ao povo, para desmoralizar os padres e a Igreja. O objetivo era transformar a procissão de Nossa Senhora da Glória numa verdadeira revolta, chamada de "Operação Canudos". No entanto, para indignação e ódio de Salgado, essa travessia resulta na conversão de Manuel Salviano, que se torna uma espécie de místico.

Indignado com esse acontecimento, Júlio Salgado comete o mais dramático ato de barbárie assassinando Mr. Wilson, um vendedor de bíblias e detetive que desconfiava de toda Operação. Nesse crime aparentemente sem sentido surge a motivação política movida pelo ódio: Salgado põe a mala de bíblias da vítima na casa de Salviano no intuito de incriminá-lo. Mesmo preso, Salviano não denuncia o ex-companheiro de partido, assumindo uma condição de mártir, por sete dias, na prisão. Esse tempo foi para ele de profunda reflexão, recusando contato até mesmo com o malfeitor Salgado, que vem lhe "tentar" para continuar o plano. O que revela uma constante oposição entre o recémcristão e o líder do Partido Comunista, isto é, Salviano e Salgado, personagens-símbolos que renovam os arquétipos do conflito apocalíptico: o Bem e o Mal, o Cristo e o Anticristo.

Ora, uma imagem só pode ser desvelada por meio do seu significado simbólico. Em As estruturas antropológicas do imaginário, Gilbert Durand (2002) concebe o imaginário como um campo medido pela extensão da "aura imaginária", e não pelo valor das imagens. Na psicanálise junguiana, essa "aura" pode ser comparada ao próprio "inconsciente coletivo", uma vasta memória de toda experiência da humanidade organizada por meio de arquétipos que "se expressam em imagens simbólicas coletivas", tendo o símbolo "como a explicação da estrutura do arquétipo" (Pitta, 2005, p. 16-17). Na concepção de Durand, todo símbolo é uma forma de expressão do próprio imaginário. Como é constante o homem buscar significância para tudo, essa disposição requer mergulhar no campo simbólico. Visando delimitar eixos para o trajeto 
antropológico, Durand propôs o método de convergência chamado de "constelações de imagens", isto é, "constelações praticamente constantes e que parecem estruturadas por um certo isomorfismo dos símbolos convergentes" (Durand, 2002, p. 43), possibilitando a análise dos mitos sempre por meio de um grande núcleo.

É por meio da análise profunda de um imaginário simbólico, arquetípico, criativo, que buscamos desvendar como a arte literária do escritor Antonio Callado (que acaba de completar seu primeiro centenário) reconstrói milenares imagens do inconsciente coletivo a partir do mergulho no contexto ideológico, religioso e social de sua época.

\section{O grande conflito}

O núcleo mítico fortemente notável na trama de Antonio Callado é o conflito apocalíptico. Nos últimos capítulos de Assunção de Salviano, assinala-se o que é coincidente com as estruturas escatológicas e milenaristas presentes no comunismo marxista, herdadas dos mitos escatológicos do mundo asiático-mediterrâneo e enriquecida pela ideologia messiânica judaico-cristã, isto é, a luta entre o Bem e o Mal e o conflito apocalíptico entre o Cristo e o Anticristo (Eliade, 1972, p. 129). Esse embate é representado pelas personagens Salviano, uma figura redentorística semelhante ao Messias; e Salgado, o Lúcifer, derrotado junto com os ideais do Partido Comunista.

Com efeito, aos olhos de Manuel Salviano, o personagem Salgado - envolvido pela influência dos arquétipos da sombra, "tentando" o recém-convertido a negar sua fé em busca do plano político do partido - mais parece uma espécie de Anticristo:

- Escute, Salviano, talvez você mesmo não tenha conseguido impedir isto que aconteceu. Mas ainda pode ser fiel à sua palavra comigo sem mentir a você mesmo. Fale na revolução agrária e ataque os padres, no dia em que for à igreja de Petrolina.

- Eu não vou à igreja de Petrolina. Aquele plano para mim morreu, seu Júlio, aquilo é obra do diabo.

- Então, eu sou o diabo, pelo visto? ...

- É, o senhor é o diabo.

Aqui, Júlio deu uma palmada na perna e realmente riu, um riso escarninho, mas riso (Callado, 1954, p. 139).

Com essa declaração, tudo que se manifestava em matéria de "Operação Canudos" passa a significar o mal. O complô contra a Igreja e os padres, a farsa e a mentira perante os companheiros camponeses, o plano de revolução a gerar a carnificina, tudo ganha intensa significação por meio da imagem das tentações do demônio. E essa caracterização se carnavaliza exatamente quando Salgado assume essa personificação, principalmente através da ironia e da chacota: "Salviano sentiu aquele sarcasmo a fundo" (Callado, 1954, p. 141).

Em O demoníaco na literatura, Antônio Magalhães e Eli Brandão afirmam que em meio às oscilações e continuidades é possível identificar, no âmbito das religiões e das ideologias, as representações do diabo na arte e no imaginário ocidental. Nesse estudo, os pesquisadores afirmam que as matrizes indicam que o diabo faz parte, sim, dos imaginários de natureza religiosa, mas é a partir da Idade Média e do Renascimento que ele ganha o status de figura, representação e força. É também na Baixa Idade Média que Agostinho recorre à figura do diabo para justificar a problemática do mal e da queda (Magalhães e Brandão, 2012).

Mas essa imagem também tem sua origem na experiência vital, provinda do pensamento numinoso. Em Escritos diversos, Jung comenta que a figura de Satanás é tema tradicional como criação artística poético-religiosa e também como mitologema, que vem originando formação de certas imagens "metafísicas" devido ao processo de cerca de dois mil anos dessa constante expressão no inconsciente coletivo. Na realidade, como ainda afirma Jung, a figura de Satanás, desde seu aparecimento obscuro nos textos do Antigo Testamento, passou por estranha evolução e só vem florescer verdadeiramente a partir do Cristianismo, assumindo a dimensão do próprio mal (Jung, 2011b). Segundo Magalhães e Brandão (2012), foi exatamente a partir do Cristianismo que o diabo obteve força no mundo por meio de representações e projeções variadas. 
No diálogo com o místico Salviano, agora dotado de uma numinosidade, Salgado se questiona sobre a anatomia constituinte de sua própria imagem, "desenhada" pelo primeiro de forma tão complexa e mutante:

- Salviano, você já está enxergando meus chifres e meu rabo?

- O Senhor até parece menino em aula de catecismo - disse Salviano.

- Menino?...

- É, sim senhor, em aula de catecismo. Quando eu aprendia catecismo menininho ainda, lá em rio do Peixe, um companheiro meu perguntou ao padre se o diabo tinha chifre e rabo e o padre disse que o diabo, que morava no inferno, tinha, mas que quando se falava no diabo querendo falar nos que gostam mais dele do que de Deus, nos que servem ao diabo em vez de servir a Deus, esses não tinha nada de diferente de ninguém, só a compadria com o diabo. Por isto é que eram perigosos. Se tivessem chifre e rabo era fácil correr deles (Callado, 1954, p. 140).

Conforme esse trecho, o que a personagem Salviano explica pode ser associado à metafísica do mitologema diabolicus de projeções variadas. Segundo o messiânico, há os que não apresentam traços de animalidade nem se parecem com as figuras de deuses. Do contrário, assemelham-se ao próprio ser humano em sua capacidade de se projetar na sombra. Para Magalhães e Brandão (2012), é na literatura que o diabo perde espaço para ser constituído por personagens complexas, principalmente após o Romantismo. Isso ocorre em obras de vários escritores: Goethe (1749-1832), William Blake (1757-1827), Balzac (1799-1850), Victor Hugo (1821-1867), Dostoiévski (1821-1881) e Baudelaire (1821-1867). Uma vasta literatura tem contribuído para renovar a imagem desse arquétipo.

A recorrência não é exceção na obra modernista inaugural de Antônio Callado. Isso porque a arte literária se torna capaz de renovar o antiquíssimo arquétipo do conflito apocalíptico que assume grande densidade na obra, graças à oposição ideológica entre a fé cristã e a ideologia comunista.

Com efeito, o personagem Salgado passa por um processo de metamorfose. De revolucionário e idealista com espírito otimista, transforma-se numa figura repleta de ódio, rancor e intolerância aos padres, à Igreja, ao misticismo religioso presente nas pregações e romarias de Manuel Salviano. Entregue ao seu lado arquetípico sombrio, Salgado se torna o símbolo de Satã: numa assimilação com "o riso escarninho" (Callado, 1954, p. 139) que é a identificação da irrisão e da ironia demoníaca. Ele entoa a voz sempre em tom de ameaça: "Cuidado, que assim você ainda acaba espetado nos cornos de diabos piores do que eu" (Callado, 1954, p. 140).

Toda essa expressão mítica se manifesta em virtude do plano maléfico de Salgado: almejava que seu próprio companheiro de Partido, Manuel Salviano, se tornasse uma espécie de "bode expiatório". E ainda, o assassinato de Mr. Wilson cometido pelo primeiro e sua conspiração para incriminar o próprio Salviano. Tudo isso conduz esse taumaturgo a uma configuração inconsciente que se manifesta em sua psique por meio da linguagem mítica da figura satânica atribuída ao impetuoso Júlio Salgado. Uma imagem primígena da sombra que se opõe à figura de Deus, ou seja, uma imagem contrastante do Deus summum bonumm e o seu oposto summum malum, postulador do equilíbrio psíquico no inconsciente coletivo, assim como se apresenta na imagética do Antigo Testamento.

É importante reafirmar também que a trajetória de Salgado, movida pelo arquétipo da sombra e marcada pelo fracasso e pela barbárie - assassinato, amor não correspondido, plano ideológico falho, "Operação Canudos ia falhar" (Callado, 1954, p. 141) - acentua um sentido extremamente negativo ao líder do partido e, consequentemente, ao Comunismo. Assim, no curso da trama de Callado, no choque provocado pelo imaginário antinômico cristianismocomunismo, o Partido Comunista também se configura como signo do Mal; e Salgado, como o Anticristo. Nesse sentido, surge em Assunção de Salviano a ideia de que o Comunismo seria um movimento que intenta revoluções, no qual a luta deve ir até as últimas consequências, não importam os meios, apenas os fins.

A tática para incriminar Salviano pelo assassinato de Mr. Wilson se nutre das monstruosidades da perversão e das trevas que afligem as almas em desespero. Ele resolve se 
esconder em frente à casa de Salviano a fim de colocar a mala de bíblias do falecido junto às ferramentas de trabalho daquele marceneiro e, assim, incriminá-lo:

Postaram-se no capinzal e aguardaram, acocorados, perto um do outro, mas separados por mundos em seus pensamentos. Júlio Salgado estava tranquilo, orgulhoso, saboreando ainda aquele medo pânico do amigo e ruminando com delícia uns versos que só agora sentia plenamente:

Comme d'outres par la tendresse

Sur t'avie et sur ta jeunesse,

Moi, je veux régner par l'effroi. ${ }^{2}$

'Para sempre - dizia ele - 'João terá medo do que eu possa dizer no seio do Partido. E o medo, por sua própria negatividade, é criador...

Pode criar até um amor'. Quanto a João, remoía com raiva a lembrança da humilhação, e começava a tornar-se consciente de um certo asco em relação a Júlio Salgado (Callado, 1954, p. 155).

Com seu companheiro de partido, João Martins, Salgado arma uma forma de condenar Salviano pelo assassinato do Mr. Wilson; uma cena guiada pela criação do medo e da maldade que dominam todo um terrorismo associado ao simbolismo nictomórfico. O líder do partido e seu amado não correspondido juntos fisicamente, mas distanciados pelo que predominava em suas psiques. O primeiro saboreando o gozo de atormentar e humilhar, modulações do mal do qual ele acredita advir um potencial criador: o desejo de possuir o seu amado pela pressão psíquica. Para Martins, todavia, é uma forma angustiante diante do medo da morte que reside no regime diurno das imagens. Uma pedagogia do medo cuja representação pode ser associada ao diabo. Isso também se justifica graças ao simbolismo teriomórfico presente no sentimento de asno e repugnância que Martins passa a nutrir por Salgado.

Após impor que Martins colocasse a mala junto às coisas de Salviano, Salgado planeja uma forma de fazer com que Irma, esposa do primeiro, a encontrasse. Em seguida, busca convencê-la de que Salviano cometeu o crime em virtude de seu ódio pelas bíblias. A princípio, parece-lhe impossível, mas o comportamento nada convencional de Salviano nos últimos tempos, como uma espécie de santo, a coloca em dúvida graças às artimanhas de Salgado, expressando todo o júbilo do reino da mentira. Apavorada com a descoberta, a esposa de Salviano não sabe que decisão tomar. É então que Salgado recomenda-lhe que "consulte a sua consciência" e o coloque "num hospício" (Callado, 1954, p. 161). Embora o rumo da trama conduza Manuel Salviano à prisão.

No momento que Irma começa a acreditar nas histórias contadas por Salgado, ele se aproveita para ressaltar os supostos motivos que fizeram Salviano matar o vendedor de bíblias:

- E a Bíblia, não foi? A senhora se lembra que me disse que Salviano tinha ficado com raiva ao encontrar a Bíblia deixada aqui?... Não foi decerto ódio à Bíblia, dona Irma, foi ódio de um Beato católico por um protestante, talvez. Foi loucura, dona Irma.

E assim, com infinita cautela, como se nada dissesse que não fosse apoiado em frases de Irma, Júlio a transformou num promotor. Quando se despediu, Irma ia vestir-se para ir à Polícia (Callado, 1954, p. 161-162).

Com astúcias provindas da sombra, Salgado consegue influenciar Irma quanto à culpa de Salviano. Faz da esposa do marceneiro taumaturgo sua "inimiga". Nesse sentido, as atitudes dessa personagem podem ser facilmente associadas ao Anticristo. Salgado representa todo esse reinado, buscando subverter valores sociais por meio do plano de carnificina que instauraria o caos em Juazeiro ("Operação Canudos") para destituir os valores religiosos em nome de um suposto devir social de bonanças para os camponeses. Mas o leitor atento percebe seus reais interesses: "os resultados não dariam para ele ir a Paris, mas pelo menos não ia ele, Júlio Salgado, assistir e ajudar o parto de um santo em Juazeiro" (Callado, 1954, p. 141).

\footnotetext{
${ }^{2}$ Igual aos outros pela ternura

Em sua vida e sua juventude,

$\mathrm{Eu}$, eu quero governar pelo terror (tradução nossa).
} 
Importante associar essa postura de Salgado ao fato de que o Anticristo é uma parte integrante da mitologia milenarista e escatológica. Eliade considera o reinado do Anticristo como o retorno do caos, sob a forma de um demônio ou dragão, rememorando a luta mítica entre Deus e o dragão. Esse confronto final teve lugar no princípio e será novamente travado no fim. Considerado também como o falso Messias, subjaz aos valores morais, sociais e religiosos a partir da secularização do mundo hodierno (Eliade, 2013).

Discordando apenas em parte com Eliade, é possível, sim, afirmar que esse confronto faz parte da mitologia escatológica e milenarista, mas reapareceu só "aparentemente" secularizado nos últimos anos em movimentos políticos totalitários, como o comunismo. "Aparentemente" porque esses elementos escatológicos de anúncio de uma era de abundância não estão imunes à ação do numinoso.

É importante também destacar como a arte literária se encarrega de recriar a imagem do próprio conflito arquetípico milenar. Em outras palavras, enquanto Salgado passa a assumir uma personificação da figura do Anticristo, Salviano segue fielmente os preceitos cristãos como seguidor do Messias, assumindo fortemente o papel redentorístico no sertão do São Francisco:

- Vocês todos que querem terra, vocês devem fugir como do diabo de quem chegar com histórias de revolução nos campos, de tomar conta das fazendas, de matar fazendeiros. Cuidado com a tentação desses homens! Não há quem entre no céu com um morto nas costas. É mais fácil um camelo passar num buraco de agulha porque a cacunda formada por um morto é maior do que três camelos inteiros (Callado, 1954, p. 132).

As tentações a que se refere o taumaturgo são as promessas fascinantes do quiliasmo marxista. Dentre os milenarismos primitivos, eles são as únicas "re-valorizações positivas modernas" que pairam no mito do fim do mundo (Eliade, 1972, p. 46). Entretanto, para Salviano, essa esperança de gozo e prazeres no plano material se constitui como uma genuína forma de se afastar da perspectiva espiritual que é a espera da salvação celeste. Alcançá-la requer uma radical recusa aos prazeres materiais e mundanos. Nesse sentido, o próprio ideário comunista dos partidários juazeirenses assume a condição simbólica do diabolicus: revoluções, intentos bélicos e assassinatos.

Além disso, a parábola bíblica tomada de empréstimo contém o complexo simbólico de acesso ao plano transcendental que requer uma mutação ontológica radical: "a iniciação, como a morte, o êxtase místico, o conhecimento absoluto, a fé (no judaísmo cristianismo), equivale a uma passagem de um modo de ser a outro" (Eliade, 1992, p. 87). A soteriologia não é para os assassinos e essa condição traz um simbolismo teriomórfico de valores intensamente negativos. Todavia, a boa-nova salviânica alerta os camponeses, coronéis e grileiros para se livrarem das tentações do sonho de um paraíso terrestre, abdicando das riquezas "fazendas", para manter vigor nos mistérios da graça da Jerusalém celeste.

Essa imagem arquetípica é abundantemente presente na imagística bíblica. Assim descreve o historiador do sagrado:

Uma Jerusalém celestial foi criada por Deus antes que a cidade fosse construída pela mão do homem; é a primeira das duas que o profeta se refere, no Apocalipse siríaco de Baruc II, 4, 2-7: 'Por acaso pensais que esta é aquela cidadã da qual Eu disse: sobre as palmas de Minhas mãos eu vos entalhei?, Este edifício agora construído em vosso meio não aquele que Me é revelado, aquele que foi preparado com antecedência aqui, na época em que Me decidi a fazer o Paraíso, tendo sido mostrado a Adão ante de ele ter pecado...' A Jerusalém celestial alimentou a inspiração de todos os profetas hebreus: Tobias 13,16; Isaías 59,11ss; Ezequiel 60, etc. Para mostrar a Ezequiel a cidade de Jerusalém, Deus o toma numa visão extática e o transporta até uma montanha muito alta. E os Oráculos Sibilinos preservam a lembrança da Nova Jerusalém, no centro da qual brilha "um templo... como uma torre gigantesca, que toca as próprias nuvens e é vista por todos..." Porém, a mais linda descrição da Jerusalém celeste ocorre no Apocalipse (21,2ss): "Vi também descer do céu, de junto de Deus, a Cidade Santa, uma Jerusalém nova, pronta como uma esposa que se enfeitou para seu marido" (Eliade, 1992, p. 15-16).

Nessa analogia, percebe-se que a imagem do mal se presentifica em tudo o quanto se refere às delícias dos prazeres de culto ao mundo material, enquanto que a valorizações do plano espiritual, 
celeste, passam a reafirmar a presença do summus bem. Posto que a arte se encarrega de "retocar" essas imagens arquetípicas graças aos entraves de cunho político, religioso e estético.

\section{A antinomia do sal na alquimia simbólica}

Convém adentrar ainda mais profundamente na riqueza simbólica que acentua a renovação desse imaginário arquetípico. Da constante oposição que constituem todas as mais diversas formas imaginais no romance, o confronto decorrente do quiliasmo marxista/Jerusalém celeste ateísmo/devoção, revolucionário/taumaturgo, inferno/céu, Cristo/Anticristo, materialismo/espiritualidade, bem/mal -, constituidor da antinomia comunismo/cristianismo, desvenda-se um complexo de natureza simbólica que está presente no próprio nome das personagens: Salgado e Salviano, personificações "compósitas" a partir do sal.

Por meio da psicologia analítica, em associações simbólicas com a alquimia, sobretudo em $A s$ personificações dos opostos, no estudo intitulado Mysterium Coniunctionis, Jung esclarece que o sal pode ser uma propriedade assassina, o mar titônico, a relação sombria com o Maleficus Saturnus. Na parábola do sulphur, o sal é representativo do papel sombrio em meio ao novilunio da Luna:

O Sal é o assassino de Sulphur, ao causar-lhe um incurabile vulnus (ferimento incurável). [...] É o paralelo raro [...] acerca do ferimento de Amforta, causado aqui pelo feminino, mas exatamente por uma colisão entre o rei do Santo Gral e seu adversário (sombra) (Jung, 2011a, p. 330, grifos do autor).

Por outro lado, o sal também segue o princípio do Eros e faz com que tudo fique perfeito (Jung, 2011a, p. 330). O sal representa o próprio Cristo, "o sal sapientiae que é dado no batismo [...]. Verbo gerado desde a eternidade para a nossa conservação" (Jung, 2011a, p. 317). Na frase bíblica clássica dirigida aos Apóstolos "vós sois o sal da Terra" (Mt 5:13) tem uma significação completa e profunda. Para Jung, é de algum modo

personificações da compreensão superior e da sabedoria divina (como a eles, por serem [...] apóstolos - e anunciadores da Boa-Nova, compete o papel de [...] anjos - a fim de que o reino de Deus na Terra se assemelhe à estrutura do reino celestial) (Jung, 2011a, p. 317).

Pois foi o Salvador que escolheu os apóstolos para serem o sal dos homens, anunciando o Evangelho incorruptível. É, também, correspondente ao relacionamento promovido pelo Eros, isto é, pelo sentimento, pela preservação da vida toda. Além disso, no Evangelho de Marcos (Mc 9:50), encontramos: "Tende o sal em vós, e a paz entre vós" e "A vossa palavra seja sempre agradável, temperada de sal, para saberdes como convém responder a cada um" (Cl 4:60) exemplos das mais antigas menções sobre o sal no Novo Testamento (Jung, 2011a, p. 317).

Constituinte do nome das duas personagens, o sal possui a genuína forma de representar os papéis de personagens opostos: Salgado e Salviano. O primeiro como o malfeitor, assassino, em constante perturbação pelo conflito com sua própria sombra. É o excesso do mar titônico "salgado" capaz até de ferir em nome do sonho regozijador do quiliasmo marxista, representado no romance de Callado principalmente pelo desejo de um amor carnal perfeito e a fama do partido. Em oposição, Salviano é o sal simbólico movido pela ação do Espírito Santo, que assume o papel redentor - "salvador" - junto às terras sertanejas, semeando a "boa-nova" do reino celestial. O que constrói uma simbólica que vem renovar na trama de Callado a imagística do conflito apocalíptico. Isso porque, no sal, estão contidos o bem e o mal (Jung, 2011a, p. 328).

\section{As antinomias divinas na consciência de Jó}

A forma como a arte literária de Assunção de Salviano revitaliza a imagem do relato bíblico de Jó é bastante intensa. $\mathrm{O}$ arquétipo do grande conflito reclama a hipótese da presença do oposto em Deus para a condição de religião monoteísta, assim magistralmente predicado por Jung.

Ora, mesmo em meio a todos os "nãos" de Salviano após sua numinosa conversão cristã, Salgado busca formas de reestabelecer seu ego humilhado. Para isso, intenta sua última cartada: 
- Muito bem, bravos, você está ficando um grande argumentador. Mas cuidado com esse orgulho, senhor santo. Você só sabe se comparar aos santos, aos eleitos, aos queridos de Deus, a Jó e companhia.

[...] só me resta o consolo de dizer que, apesar de diabo, não deixei de servir a Deus, dandolhe esta brilhante alma que é sua. Um papel novo, esse diabo.

- Não é não, seu Júlio. Ontem de noite eu estava pensando nisto, como é que um homem do diabo podia fazer tanto bem a um homem que tinha perdido Deus, e fui ver na história de Jó que o diabo de vez em quando vem à terra para tentar os homens de Deus. E não ganha, não. Deus deixa seus homens sozinhos, mas o diabo falha (Callado, 1954, p. 140-141).

Entre as variadas interpretações do mito de Jó, a resposta da personagem Salviano nos remonta ao diálogo com Jung, especificamente em Resposta a Jó. Segundo o fundador da psicologia analítica, nesse mito se apresenta tanto a onipotência de Deus como Sua natureza antinômica, atrelado à confiança de que Jó era um homem justo. Nessa concepção, o sofrimento de Jó faz parte de um jogo de aposta divina, mas esse personagem bíblico conhece a antinomia interior de Javé. Esse fato acarreta uma evolução, isto é, uma semelhança com Deus em virtude do conhecimento sobre a numinosidade divina (Jung, 2011b).

$\mathrm{Na}$ análise dessa problemática, enveredando pelos acontecimentos simbólicos, mesmo sem deixar de descrever a experiência pessoal que se faz presente nas emoções subjetivas de uma verdade não eterna, Jung se propõe a compreender a antinomia de Javé:

Talvez o que de mais elevado haja em Jó seja que ele, em face de uma dificuldade como esta, não se perturbe com a unidade de Deus, percebendo claramente que Deus se harmoniza tão perfeitamente consigo próprio, que Jó tem a certeza de que encontrará em Deus um advogado e defensor contra o próprio Deus. Tão certa é para ele a existência do bem em Javé quanto a existência do mal. Não se pode esperar um defensor na pessoa de um homem que não pode fazer-nos o mal. Mas Javé não é um homem. Ele é, a um só tempo, perseguidor e defensor, e nessa situação um dos aspectos é tão real quanto o outro. Javé não se acha dividido, mas constitui uma antinomia, isto é, uma oposição interna total, que é a condição preliminar e necessária de seu imenso dinamismo intrínseco, de seu poder e ciência infinitos. A partir deste conhecimento, Jó persiste no propósito de "expor seu modo de proceder" a Javé, ou seja, insiste em lhe explicar o seu ponto de vista, pois apesar da sua ira, Javé, contra si próprio, é também defensor do homem que lhe apresentou queixa (Jung, 2012b, p. 20-21).

Na trama calladiana, ao descrever o papel do diabo, Manuel Salviano reconhece essa dualidade divina e o papel de Salgado em tentar, mesmo que o primeiro se alimentasse de intenções revolucionárias, odiando o verbo divino, os padres e a Igreja. Porém, Salviano deixou de se aliciar com Satanás quando, por meio de sua conversão, desvenda a natureza antinômica de Deus:

Queria atacar seu Hóspede e Hóspede que como tinha descoberto sempre tinha morado em sua casa [...] Deus também agora não se importava mais de lhe tomar o tempo todo sempre no meio da casa como se Salviano finalmente tivesse voltado do trabalho e pudesse dizer: "Fique à vontade Senhor que já serrei tudo que tinha de serrar e não há mais falta de mesas no mundo podemos conversar indefinidamente não preciso nem fazer o bule de café" (Callado, 1954, p. 171-172).

Essa experiência se assemelha com a mística de São João da Cruz, onde a conversão se reveste de toda feição: Deus vem como amigo, mas o homem pode acolher ou olvidar. Se o recusa, a atividade da alma torna-se alheia a Ele; se O recebe, jaz uma imensa energia da graça santificante. Eis a experiência da "segunda conversão":

Ei-la que, pressurosa, se acerca do Hóspede, procura agradá-lo; já a divina presença torna-se mais atuosa e dirige algumas iniciativas da alma [...] Na medica exata em que se removem os obstáculos e se expulsam os intrusos, cresce a intimidade, estreita-se a relação; começa a alma a experimentar a presença do Deus interior: desponta a vida mística (Penido, 1949, p. 64). 
Para Jung, Javé trava uma aposta com Satanás quanto à fidelidade de Jó. De maneira análoga, o diabólico Salgado intenta o mesmo, mas fracassa, pois Salviano alcança uma fé cristã inabalável. Através do contato com a força, a atração e o fascínio que possui a numinosidade do confronto intradivino, Salviano começa a participar dessa experiência íntima com o Summum Bonumm:

Assim tinha Deus entrado com alarido pela sua alma no dia em que ele abrira não sabia que barragens há muito solidificadas a montante do coração ressequido. [...] aquilo que enunciava como mentira no mesmo instante se cristalizava em rocha e verdade dentro de sua própria boca (Callado, 1954, p.165-167).

Nessa ficcionalizada, utópica, onírica, messiânica e apocalíptica "aposta", o comunismo falha e o cristianismo vence. $\mathrm{O}$ arquétipo da busca do paraíso perdido também é profundamente renovado pela arte literária. Isso porque essa sede arquetípica de Salviano abdica do quiliasmo marxista e "decola" intensamente na espera do paraíso celeste através do simbolismo aquático cristão:

meio desesperado ele mesmo por ter tão pouco tempo para pensar em Deus e na Hora da Morte, fechava os olhos um instantezinho, só mesmo o tempo de recolher na fronte e na boca um borrifo que fosse da água da morte que o fazia logo reviver. Sabendo que tudo o que falava tomava logo densidade e endurecia na sua frente para nunca mais desaparecer (Callado, 1954, p. 170).

Para Eliade, esse simbolismo revela o sentido mais profundo através da significação hierofânica de santificação: "O que outrora curava o corpo cura hoje a alma; o que dava saúde no tempo dá salvação na eternidade... $\mathrm{O}$ 'homem velho' morre por imersão na água e dá nascimento a um novo ser regenerado" (Eliade, 1979, p. 149). Esse simbolismo apresenta semelhança com o batismo de Cristo no Jordão, uma descida às Águas da Morte para um "um duelo com o monstro marinho". Desse modo, ao descer às águas, Jesus "amarrou o (que é) forte com força, a fim de que nós adquiríssemos o poder de caminhar sobre os escorpiões e serpentes" (Eliade, 1979, p. 150).

Pela numinosidade que reside na renovação de toda essa imagística do conflito apocalíptico, as atitudes da personagem Salviano são surpreendentes. Os episódios finais da trama narram a profunda resignação de Salviano na prisão. Ele não se esforça de forma alguma para provar sua inocência, apesar da insistência de Ritinha e do pedido de perdão de sua esposa Irma. Semelhante a Cristo, assume a condição de mártir: não se alimenta e apenas se fecha interiormente nos seus pensamentos e orações na busca de herdar a Jerusalém celeste: "Tinha pegado a 'Santa Maria' para desbastá-la como quem desbasta um bonito pau de canela, para descobrir os desenhos do cerne da oração" (Callado, 1954, p. 168-169).

Enquanto isso, Júlio Salgado manifesta toda sua indignação:

a desilusão que toda aquela gente das redondezas ia ter com "São" Salviano dentro de algumas horas, de certa forma compensava: o polivéu ignorante veria em que dava aquela estupidez de seguir taumaturgos em lugar de seguir líderes revolucionários (Callado, 1954, p. 141).

Numa constante oposição que perdura a segunda metade do romance calladiano, Manuel Salviano cumpre o destino do Redentor até o fim - a Assunção - e segue o exemplo arquetípico de Cristo. Entretanto, numa situação bem sarcástica e humorística, dada as circunstâncias de sua ascensão. Após a morte de Salviano na cadeia, o delegado, o prefeito e padre Generoso decidem tirar o morto pelo telhado, com medo da reação da multidão que se encontrava fora da delegacia. Inquietos pela demora em autorizar a visitação ao taumaturgo, o povo invade a delegacia e presencia a cela de Salviano vazia com o telhado aberto para o céu. Nesse instante, homologa-se popularmente um redentor dos camponeses, ou seja, uma espécie de messias ou simplesmente um profeta como Elias que foi arrebatado: "- Salviano subiu pr'o céu! responderam mil bocas" (Callado, 1954, p. 219).

Compreende-se essa passagem recorrendo à iconografia do conhecimento sagrado: a abertura superior detém o significado da "direção ascensional para o Céu, o desejo de transcendência". É também a possibilidade de passagem do profano ao sagrado (Eliade, 1992, p. 87).

Orientado pela negação de sua condição material humana, Salviano renuncia às vontades profanas na busca do transcendente. É pela condição de finitude e limitação humana que o homem busca a 
graça infinita da perfeição divina. Quando a arte literária redesenha o papel do grande conflito como anunciador de outro porvir, repleto da "sede" primígena da bem-aventurança.

Em suma, em Assunção de Salviano, o conflito apocalíptico e o sonho de alcançar a Jerusalém celeste e o paraíso perdido, pela doutrina cristã e pelo comunismo, respectivamente, são protagonizados por meio do confronto entre as personagens Salviano e Salgado, representação dos arquétipos do Cristo e do Anticristo. Nessa hermenêutica, percebe-se que a oposição entre cristianismo e comunismo adquire dimensão simbólica graças ao modo como a literatura calladiana "fabrica" novas imagens sagradas a partir desses arquétipos. O que contribui para redimensionar duas principais significações: o papel negativo do ideário político comunista e a valorização positiva da doutrina cristã.

\section{Referências}

BACHELARD, Gaston (2013). A terra e o devaneio da vontade: ensaio sore a imaginação das forças. Tradução de Maria Ermantina de Almeida P. Galvão. São Paulo: Martins Fontes.

CALLADO, Antonio (1954). Assunção de Salviano. Rio de Janeiro: José Olympio Editora.

DURAND, Gilbert (2002). As estruturas antropológicas do imaginário: introdução à arquetipologia geral. Tradução de Hélder Godinho. São Paulo: Martins Fontes.

ELIADE, Mircea (s/d). Mito do eterno retorno. Tradução de José A. Ceschin. São Paulo: Mendonça.

ELIADE, Mircea (1972). Mito e realidade. São Paulo: Perspectiva.

ELIADE, Mircea (1979). Imagens e símbolos. Lisboa: Minerva.

ELIADE, Mircea (1992). O sagrado e o profano. Tradução de Rogério Fernandes. São Paulo: Martins Fontes.

ELIADE, Mircea (2000). Mitos, sonhos e mistérios. Tradução de Samuel Soares. Lisboa: Edições 70.

ELIADE, Mircea (2008). Tratado de história das religiões. Tradução de Fernando Tomaz e Natália Nunes. São Paulo: Martins Fontes.

ELIADE, Mircea (2013). Mito e realidade. Tradução de Pola Civelli. São Paulo: Perspectiva.

JUNG, Carl Gustav (s/d). O homem e seus símbolos. Tradução de Maria Lúcia Pinho. 5. ed. Rio de Janeiro: Nova Fronteira.

JUNG, Carl Gustav (2011a). Mysterium Coniunctionis: os componentes da coniunctio, paradoxa, as personificações dos opostos. Petrópolis: Vozes.

JUNG, Carl Gustav (2011b). Escritos diversos. Tradução de Mateus Ramalho Rocha e Lúcia Orth. Petrópolis: Vozes.

JUNG, Carl Gustav (2012a). Os arquétipos e o inconsciente coletivo. Tradução de Maria Luiza Appy e Dora Mariana R. Ferreira da Silva. Petrópolis: Vozes.

JUNG, Carl Gustav (2012b). Resposta a Jó. Tradução de Mateus Ramalho Rocha. Petrópolis: Vozes.

KUJAWSKI, Gilberto de Mello (1994). O sagrado existe. São Paulo: Ática.

MAGALHÃES, Antonio; BRANDÃO, Eli (2012). O diabo na arte e no imaginário ocidental. In: MAGALHÃES, Antonio et al. (Orgs.). O demoníaco na literatura. Campina Grande: EDUEPB.

OTTO, Rudolf (2007). O sagrado: os aspectos irracionais na noção do divino e sua relação com o racional. Tradução de Walter O. Schlupp. São Leopoldo: Sinodal/EST; Petrópolis: Vozes.

PENIDO, Maurílio Teixeira Leite (1949). O itinerário místico de São João da Cruz. Petrópolis: Vozes.

PITTA, Danielle Perin Rocha (2005). Iniciação à teoria do imaginário de Gilbert Durand. Rio de Janeiro: Atlântica. 